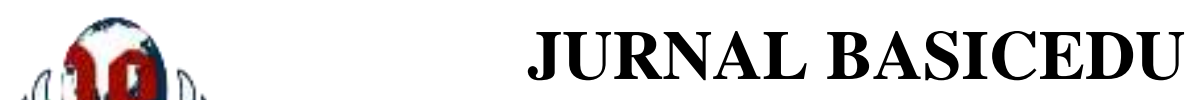

Volume 5 Nomor 5 Tahun 2021 Halaman 4206 - 4211

Research \& Learning in Elementary Education

https://jbasic.org/index.php/basicedu

\title{
Pengaruh Media Educandy pada Pembelajaran PPKn terhadap Motivasi Belajar Daring Siswa Sekolah Dasar
}

\author{
Anindya Mirza Kurnia Putri ${ }^{1 凶}$, Akhwani $^{2}$, Nafiah $^{3}$, Muhammad Syukron Djazilan ${ }^{4}$ \\ Universitas Nahdlatul Ulama Surabaya, Indonesia ${ }^{1,2,3,4}$

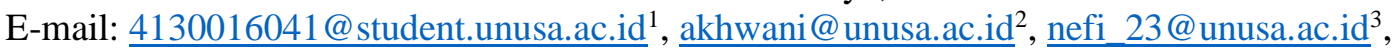 \\ syukrondjazilan@unusa.ac.id ${ }^{4}$
}

\begin{abstract}
Abstrak
Penelitian ini bertujuan untuk mengetahui penggunaan media Educandy terhadap motivasi belajar daring siswa IV SD Ganting Sidoarjo, meningkatkan motivasi belajar pada siswa kelas yang menggunkan media Educandy pada pembelajaran PPKn dan motivasi belajar siswa pada kelas yang tidak menggunakan media Educandy pada pembelajaran PPKn. Populasi dalam penelitian ini adalah seluruh siswa kelas IV SDN Ganting Kecamatan Gedangan Sidoarjoyang terdiri 2 kelas (rombel) dengan jumlah seluruh siswanya 56 siswa, kelas 4A 28 dan kelas 4B 28 siswa.Penelitian ini menggunakan metode kuasi eksperimen (Quasi Experiment Design), Sugiono (2016). bentuk desain Quasi Experiment yang di gunakan penelitian ini yaitu Nonequivalent control group design hampir sama dengan presentposteest control group desain dengan teknik pengumpulan data menggunakan kuesioner atau angket melalui surve kusioner secara langsung. Data yang diperoleh diuji menggunakan statistic deskriptif melalui aplikasi SPSS.Berdasarkan hasil dari penelitian ini menyatakan bahwa media educandy berpengaruh terhadap motivasi belajar siswa kelas IV SDN Ganting Kabupaten Sidoarjo dengan nilai Sig sebesar 0,000, media educandy pada pembelajaran PPKn berpengaruh terhadap motivasi belajar siswa.
\end{abstract}

Kata Kunci: Media Educandy, Motivasi Belajar, Pembelajaran PPKn.

\begin{abstract}
This study aims to determine the use of Educandy media on online learning motivation of fourth-grade students at Ganting Sidoarjo Elementary School, increase learning motivation in class students who use Educandy media in Civics learning and student learning motivation in classes that do not use Educandy media in Civics learning. The population in this study was all fourth-grade students at SDN Ganting, Gedangan District, Sidoarjo which consisted of 2 classes (rombel) with a total of 56 students, class $4 A 28$ and class $4 B 28$ students. This study uses a quasi-experimental method (Quasi Experiment Design). The form of Quasi Experiment design used in this study is the Nonequivalent control group design, almost the same as the present-posttest control group design, with data collection techniques using questionnaires or questionnaires through direct questionnaire surveys. The data obtained were tested using descriptive statistics through the SPSS application. Based on the results of this study, it is stated that Educandy media affects the learning motivation of fourth-grade students at SDN Ganting, Sidoarjo Regency with a Sig value of 0.000, Educandy media in Civics learning affects student learning motivation.
\end{abstract}

Keywords: Educandy Media, Learning Motivation, Civics Learning.

Copyright (c) 2021 Anindya Mirza Kurnia Putri, Akhwani, Nafiah, Muhammad Syukron Djazilan

$\triangle$ Corresponding author :

Email : 4 4130016041@student.unusa.ac.id

DOI : $\quad$ https://doi.org/10.31004/basicedu.v5i5.1537

ISSN 2580-3735 (Media Cetak)

ISSN 2580-1147 (Media Online)

Jurnal Basicedu Vol 5 No 5 Tahun 2021

p-ISSN 2580-3735 e-ISSN 2580-1147 
4207 Pengaruh Media Educandy pada Pembelajaran PPKn terhadap Motivasi Belajar Daring Siswa Sekolah Dasar - Anindya Mirza Kurnia Putri, Akhwani, Nafiah, Muhammad Syukron Djazilan DOI: https://doi.org/10.31004/basicedu.v5i5.1537

\section{PENDAHULUAN}

Pendidikan merupakan investasi untuk mempersiapkan masa depan. Melalui pendidikan, anak dididik untuk menjadi pribadi yang cerdas dan berkarakter. Pendidikan memiliki peran sebagai sarana pembentukan karakter anak. Era globalisasi yang semakin berkembang, degradasi moral terus melanda bangsa. Degradasi moral seperti korupsi menjadi permasalahan bangsa dari tahun ke tahun. Berbagai sanksi telah diberikan namun korupsi justru terus bertambah dari hari kehari.

Dikutip dari BeritaSatu.com, Indonesia masih menjadi salah satu negara yang memiliki masalah terbesar di bidang korupsi, mulai dari suap hingga kolusi masih merajalela, sehingga menjadi faktor penghambat pembangunan ekonomi, sosial, politik, dan budaya bangsa (Sukoyo, 2020). Salah satu alasan seseorang berani melakukan tindak pidana korupsi adalah karena adanya kesempatan. Dalam teori Willingness and Opportunity, korupsi terjadi karena ada kesempatan akibat lemahnya sistem atau kurangnya pengawasan, serta keinginan yang didorong sifat serakah (Putri, 2019). Data yang dihimpun oleh Transparency International tentang Corruption Perception Index pada tahun 2019 menunjukkan Indonesia memiliki skor 40 dari 100, skor 100 adalah yang terbersih. Indonesia berada di urutan ke-85 dari 198 negara di dunia (Transparency International tentang Corruption Perception Index, 2019).

Upaya pencegahan korupsi di bidang pendidikan sebenarnya telah dilakukan. Instruksi Presiden Nomor 5 Tahun 2004 tentang Percepatan Pemberantasan Korupsi berupaya menyusun buku Model Pengintegrasian Pendidikan Antikorupsi pada Mata Pelajaran Pendidikan Kewarganegaraan (PKn) mulai jenjang pendidikan dasar hingga menengah. Pada tahun 2017 disempurnakan dan dipergunakan dalam kegiatan workshop dan disebarluaskan, sehingga dapat dijadikan sebagai dasar pembelajaran di sekolah guna mengarahkan siswa untuk mengenal dan mengimplementasikannya dalam kehidupan sehari-hari (Sadar \& Fajar, 2017:2).

Sekolah Dasar merupakan pondasi awal pendidikan yang sangat berperan dalam proses tumbuh kembang anak. Siswa Sekolah Dasar mulai diperkenalkan dengan banyak hal, termasuk pendidikan atau nilai-nilai antikorupsi (A. Akhwani, 2019, Mazid et al., 2019:45). Pengenalan antikorupsi yang dilakukan melalui jalur pendidikan merupakan usaha sadar guna mengarahkan dan mencetak tingkah laku individu ke arah yang baik. Sehingga diharapkan generasi muda calon pemimpin bangsa mampu membangun nilai-nilai antikorupsi yang melekat pada karakter dirinya (Sadar \& Fajar, 2017:3). Akhwani \& Nurizka (2021:447) juga menyatakan bahwa pendidikan jenjang Sekolah Dasar merupakan sebuah fondasi yang akan menjadi penyokong pendidikan selanjutnya.

Menciptakan generasi antikorupsi tentu bukanlah hal yang mudah, generasi tersebut tidak muncul secara langsung melainkan melalui proses (Mazid et al., 2019:45). Oleh sebab itu, diperlukannya upaya atau strategi yang terprogram, holistik, dan memiliki tolok ukur yang jelas dalam pelaksanaannya. Tolok ukur yang jelas untuk memberantas korupsi akan membuat program tersebut dapat diteruskan pada generasi selanjutnya (Malau \& Laura, 2014:95).

Strategi implementasi pendidikan antikorupsi dilaksananakan dengan cara mengintegrasikan nilai-nilai antikorupsi ke dalam pembelajaran melalui (a) mata pelajaran yang sesuai, (b) muatan lokal, dan (c) pengembangan diri (Widyastono, 2013:203). Implementasi pendidikan antikorupsi melalui mata pelajaran dan muatan lokal merupakan upaya yang nampak dan cenderung mudah diterapkan sekolah karena terintegrasi dalam mata pelajaran. Sementara pada sisi pengembangan diri berada di luar ranah mata pelajaran dan perlu untuk digali dan dipelajari formatnya.

Ekstrakurikuler merupakan strategi yang termasuk dalam kegiatan pengembangan diri. Tidak seperti strategi yang lain, implementasi nilai-nilai antikorupsi melalui pengembangan diri ini dilakukan di luar kelas, sehingga memberikan kesempatan kepada siswa untuk mengeksplorasi dan mengekspresikan diri sesuai dengan potensi, bakat, dan minat. Di sisi lain setiap anak memiliki bakat dan peminatan yang tidak sama. 
Selain ekstrakurikuler, bentuk pengembangan diri yang lain adalah pembiasaan. Segala teori maupun pembelajaran yang telah disampaikan seyogianya dapat dibiasakan dan dilakukan secara berulang-ulang hingga diimplementasikan dalam keseharian. Pembiasaan (habituation) merupakan perwujudan atas pemahaman, keterampilan, serta sikap dan karakter yang telah dipelajari selama ini (Ibnatul \& Muthoharoh, 2013:7). Pada prinsipnya, terbentuknya suatu kebiasaan adalah karena adanya pengulangan. Semakin sering suatu kegiatan diulang maka kemungkinan kegiatan tersebut menjadi kebiasaan semakin kuat, terlebih pengulangannya dilakukan dalam jangka waktu yang lama (Listiana, 2019:13) .

Dengan mencermati tiga implementasi antikorupsi melalui pembelajaran nampak bahwa aspek pengembangan diri penting untuk dianalisis lebih lanjut. Kedua aspek lain seperti mata pelajaran dan muatan lokal sudah banyak diungkapkan dan implementasinya berada di ruang kelas. Berbeda dengan pengembangan diri yang dilakukan melalui ekstrakurikuler dan pembiasaan. Keduanya dilakukan diluar materi pelajaran namun dapat menjadi sarana pendidikan karakter bagi siswa sekolah dasar. Penelitian ini bertujuan untuk

\section{METODE}

Penelitian ini bertujuan untuk mengetahui pengaruh Media Educandy Terhaadap Motivasi Belajar. Metode yang digunakan dalam penelitian ini yaitu metode kuasi eksperimen (Quasi Experiment Design), Sebelum diberi treatment, baik kelompok eksperimen dan kelompok kontrol diberi test yaitu pretest, dengan maksud untuk mengetahui keadaan kelompok sebelum treatment. Kemudian setelah diberikan treatment, kelompok eksperimen dan kelompok kontrol diberikan test yaitu posttest, untuk mengetahui keadaan kelompok setelah treatment. Bentuk desain quasi eksperiment yang digunakan dalam penelitian ini yaitu nonequivalent control group design. Pada penelitian ini, penggunaan teknik pengumpulan data menggunakan kuesioner atau angket. Teknik analisis data yang digunakan adalah statistik deskriptif. Sebelum melakukan analisis data dengan independent sampel T-Test ada beberapa uji prasyarat yang harus dilakukan terlebih dahulu, yaitu: Uji Validitas, Uji Reliabilitas Angket Motivasi Belajar, Uji Normalitas, Uji Homogenitas, dan Uji Independent Sample TTest.

\section{HASIL DAN PEMBAHASAN}

Hasil penelitian yang telah dilaksanakan oleh peneliti pada tanggal 29 Maret 2021 di Sekolah Dasar Negeri Ganting Sidoarjo dengan sasaran penelitian yaitu kelas IV SD dengan jumlah siswa sebanyak 56 menggunakan pembelajaran PPKn pada materi keberagaman karakteristik individu dalam kehidupan sehari hari. Hasil penelitian meliputi:

Tabel 1

Hasil Uji Normalitas Data

\begin{tabular}{|c|c|c|c|}
\hline \multicolumn{4}{|c|}{ One-Sample Kolmogorov-Smirnov Test } \\
\hline & & kelasA & kelasB \\
\hline $\mathrm{N}$ & & 32 & 32 \\
\hline \multirow{2}{*}{$\begin{array}{l}\text { Normal } \\
\text { Parameters }{ }^{\mathrm{a}, \mathrm{b}}\end{array}$} & Mean & 71,06 & 93,06 \\
\hline & $\begin{array}{l}\text { Std. } \\
\text { Deviation }\end{array}$ & 11,210 & 3,089 \\
\hline \multirow{3}{*}{$\begin{array}{l}\text { Most Extreme } \\
\text { Differences }\end{array}$} & Absolute & 0,139 & 0,154 \\
\hline & Positive & 0,078 & 0,154 \\
\hline & Negative & $-0,139$ & $-0,119$ \\
\hline Test Statistic & & 0,139 & 0,154 \\
\hline Asymp. Sig. (2 & led) &, $120^{c}$ &, $052^{\mathrm{c}}$ \\
\hline
\end{tabular}


Berdasarkan Tabel 4.3 menyatakan bahwa pengujian normalitas dengan menggunakan SPSS 25 menghasilkan nilai signifikansi sebesar 0,120>0,005 dan 0,052>0,005 sehingga dapat disimpulkan bahwa data berdistribusi normal. Data motivasi belajar siswa kelas IV diperolah dari angket motivasi belajaryang terdiri dari 20 butir pertanyaan dengan rentang skor 1 sampai 4 yang diberikan kepada responden sebanyak 56 siswa, yaitu kelas IV-A dan kelas IV-B. Kelas A merupakan kelas kontrol dan kelas B merupakan kelas Eksperimen. Setelah data yang ada diuji normalitas dan terbukti berdistribusi normal, makalangkah selanjutnya yaitu data yang ada dapat di uji menggunakan UjiIndependent Sample T-Test berbantuan SPSS25 untuk mengetahui adanya perbedaan kelas yang menggunakan media educandy dengan kelas yang memakai pengajaran konvensional.

Tabel 2

Hasil Uji T-Test

Independent Samples Test

\begin{tabular}{|c|c|c|c|c|c|c|c|c|c|c|}
\hline \multicolumn{4}{|c|}{$\begin{array}{c}\text { Levene's Testfor Equality of } \\
\text { Variances }\end{array}$} & \multicolumn{7}{|c|}{ t-test for Equality of Means } \\
\hline & & \multirow[b]{2}{*}{$\mathrm{F}$} & \multirow[b]{2}{*}{ Sig. } & \multirow[b]{2}{*}{$\mathrm{t}$} & \multirow[b]{2}{*}{ Df } & \multirow[b]{2}{*}{$\begin{array}{l}\text { Sig. }(2- \\
\text { tailed) }\end{array}$} & \multirow[b]{2}{*}{$\begin{array}{c}\text { Mean } \\
\text { Difference }\end{array}$} & \multirow[b]{2}{*}{$\begin{array}{l}\text { Std. Error } \\
\text { Difference }\end{array}$} & \multicolumn{2}{|c|}{$\begin{array}{l}95 \% \text { Confidence } \\
\text { Interval of theDifference }\end{array}$} \\
\hline & & & & & & & & & Lower & Upper \\
\hline \multirow{2}{*}{ motivasi } & $\begin{array}{c}\text { Equal } \\
\text { variances } \\
\text { assumed }\end{array}$ & 32,073 & 0,000 & \begin{tabular}{|l}
$-10,702$ \\
\end{tabular} & 62 & 0,000 & $-22,000$ & 2,056 & $-26,109$ & $-17,891$ \\
\hline & $\begin{array}{c}\text { Equal } \\
\text { variances } \\
\text { not } \\
\text { assumed }\end{array}$ & & & $-10,702$ & 35,682 & $\mathbf{0 , 0 0 0}$ & $-22,000$ & 2,056 & $-26,170$ & $-17,830$ \\
\hline
\end{tabular}

Berdasarkan Tabel 4.9 dapat diketahui bahwa nilai Sig. Levene's Test for Equality of Variances adalah 0,000 Untuk mengetahuai hipotesis terbukti atau tikadapat diketahui jika nilai Sig.(2-tailed) $<0,05$ maka H0 ditolak dan H1 diterima. Sebaliknya, Jika nilai Sig.(2-tailed) > 0,05 maka H0 diterima dan H1 ditolak $<0,005$ yang berarti $\mathrm{H} 1$ dapat diterima dan tolak H0 karena ada perbedaan yang signifikan (nyata) antara motivasi belajar siswa kelas kontrol dengan kelas eksperimen. Hasil uji statitistik dengan menggunakan Uji T diketahui nilai 0,000< 0,05 maka $\mathrm{H} 0$ ditolak dan $\mathrm{H} 1$ diterima. Artinya ada perbedaan yang signifikan (nyata) antara motivasi belajar siswa kelas kontrol dengan kelas eksperimen. Dengan demikian dapat diketahui bahwa terdapat pengaruh media educandy terhadapmotivasi bela Siswa Kelas IV SDN Ganting Sidoarjo.

\section{Pengaruh penggunaan media Educandy terhadap motivasi belajar daring siswa kelas IV SDN Ganting Kabupaten Sidoarjo}

Pada motivasi belajar siswa kelas IV-B yang dalam hal ini menjadi kelas eksperimen berjumlah 32 siswa dengan perolehan skor minimum 44, skor tertinggi 81, dan rata-rata (mean)71,06. Hasil ini menjadikan motivasi belajar siswa kelas IV-B berada dalam kategori sedang dengan presentase 56\% yang menunjukkan bahwa kelas kontrol dalam penelitian ini memiliki motivasi belajarlebih rendah dibandingkan dengan kelas eksperimen dan motivasi belajar siswa kelas IV-B yang dalam hal ini menjadi kelas eksperimen berjumlah 32 siswa dengan perolehan skor minimum 88, skor tertinggi 99, dan rata-rata (mean) 93,06. Dengan presentase 100\% hasil ini menjadikan motivasi belajar siswa kelas IV-B berada dalam kategori tinggi.

Hasil uji normalitas untuk kelas kontrol dan kelas eksperimen menunjukkan bahwa data berdistribusi normal yantu dengan hasil 0,120>0,005 kelas IV-A dan 0,052 > 0,005 kelas IV-B, sehingga dapat dilakukan uji hipotesis dengan menggunakan uji $\mathrm{T}$. 
Hasil uji hipotesis sesuai dengan hipotesis awal yang menyatakan bahwa ada pengaruh media educandy terhadap motivasi belajar siswa kelas IV SDN Ganting Sidoarjo. Hal tersebut dibuktikan oleh hasil uji SPSS dengan nilai Sig pada tabel sebesar 0,000 < 0,05. Maka dapat disimpulkan bahwa hipotesis 1(H1) diterima.

Hal ini menunjukkan bahwa media educandy berpengaruh terhadap motivasibelajar siswa. Fakta ini sejalan dengan penelitian oleh Widiasih (2017) bahwa pembelajaran dengan menggunakan media pembelajaran berpengaruh pada motivasi belajar siswa dan Nafiah (2020) penggunaan media dalam setiap pembelajaran dapat meningkatkan motivasi belajar siswa. Pembelajaran PKn penting adanya bagi seluruh peserta didik di Indonesia. Oleh sebab itu penyampaian guru terhadap peserta didik pada pembelajaran sangat berpengaruhpada berhasil tidaknya suatu pembelajaran. Pembelajaran dengan menggunakan media terbukti memiliki pengaruh yang signifikan, meskipun pada prakteknya masih banyak guru-guru sekolah dasar yang mengajarkan PKn dengan menggunakan metode ceramah.

\section{KESIMPULAN}

Berdasarkan hasil penelitian yang dilakukan pada siswa kelas IV SDN Ganting Sidoarjo, maka tidak ada pengaruh Motivasi belajar siswa pada kelas yang tidak menggunakan media Educandy pada pembelajaran PPKn hasil perolehan skor minimum di kelas IV-B adalah 44 dan skor tertinggi 81. Sedangkan ada pengaruh terhadap Motivasi belajar siswa pada kelas yang menggunakan media Educandy pada pembelajaran PPKn, karena kelas ini menjadi kelas Eksperimen yang memperoleh hasil skor minimum 88 dan skor tertinggi 99. Sehingga tolak $\mathrm{H} 0$ dan terima H1. Temuan penelitian ini menunjukkan adanya hubungan positif antara media educandy dengan motivasi belajar siswa sekolah dasar di masa pandemic covid-19.

\section{DAFTAR PUSTAKA}

Akhwani, A. (2018). Pembelajaran PPKn Dengan Value Clarification Technique Berbantuan Role Playing Terhadap Keterampilan Intelektual Siswa SMA. Education and Human Development Journal, 3(2).

Akhwani, A. (2019). Strategy of Digital Etiquette Education Of Elementary School Students. Primary EduJournal of Primary Education, 3(2), 43-54.

Akhwani, A., \& Nurizka, R. (2021). ). Meta-Analisis Quasi Eksperimental Model Pembelajaran Value

Clarification Technique (VCT) Terhadap Prestasi Belajar Siswa Sekolah Dasar. Jurnal Basicedu, 5(2), 446454.

Sukron, M. D. (2018). Sosialisasi Urgensi Etiket Digital Bagi Santri Zaman Now Di Pondok Pesantren Salafiyah Cokrokertopati Kabupaten Magetan. Community Development Journal, 2(1), 93-102.

Arif, D. B. (2012). Kontribusi Mata Kuliah Pendidikan Kewarganegaraan Untuk Pengembangan Karakter Bangsa: Prospek Dan Tantangan Di Tengah Masyarakat Yang Multikultural. Didaktika 1(1), 85-98.

Azhar, A. (2011). Media pembelajaran. Jakarta: PT Raja Grafindo Persada.

Azwar. Saifuddin. 2013. Metode Penelitian. Yogyakarta: Pustaka Pelajar Depdiknas (2006). Permendiknas No 22 Tahun 2006 Tentang Standar Isi. Jakarta: Depdiknas.

Enshanty, Y. (2020, Desember 16). Blended Learning sebagai Metode Pembelajaran di Era New Normal. https://www.pasundanekspres.co/

Falahudin, I. (2014). Pemanfaatan media dalam pembelajaran. Jurnal Lingkar Widyaiswara, 1(4), 104-117.

Ghirardini, B. (2011). E-Learning Methodologies. Germany : Federal Ministry of Food. Agriculture and Consumer Protection.

Hamalik, O. (2011). Proses Belajar Mengajar. Jakarta: PT. Bumi Aksara.

Hamdi, Asep Saepul. E. Bahruddin. 2014. Metode Penelitian Kuantitatif Aplikasi dalam Pendidikan. Yogyakarta: (Deepublisher). 
4211 Pengaruh Media Educandy pada Pembelajaran PPKn terhadap Motivasi Belajar Daring Siswa Sekolah Dasar - Anindya Mirza Kurnia Putri, Akhwani, Nafiah, Muhammad Syukron Djazilan DOI: https://doi.org/10.31004/basicedu.v5i5.1537

Hartanti, D. (2019). Meningkatkan Motivasi Belajar Siswa Dengan Media Pembelajaran Interaktif Game Kahoot Berbasis Hypermedia. Prosiding Seminar Nasional PEP, (Vol.1, No.1).

Isman, M. (2016). Pembelajaran Moda Dalam Jaringan (Moda Daring). Publikasi Ilmiah UMS.

Kariadi, D. (2017). Menciptakan Generasi yang Berwawasan Global Berkaraketer Lokal Melalui Harmonisasi

Nilai Kosmopolitan dan Nasionalisme dalam Pembelajaran PKn. Jurnal Pancasila dan Kewarganegaraan, 1 (2).

Lestari. S. P. (2020). Asyik Dengan Educandy. Jakarta: https://bdkjakarta.kemenag.go.id/.

Ma'arif, S. (2012). Transformatif Learning Dlam Membangun Pesantren Bebasis Multikultural. Jurnal Pembangunan Pendidikan Fondasi dan Aplikasi, 1(1).

Maolani, R. A. (2015). Metodologi Penelitian Pendidikan. Depok: Raja Grafindo Persada.

Nafiah, N., \& Hartatik, S. (2020). Penerapan Manajemen Pembelajaran Berbasis Daring Dengan Menggunakan Aplikasi Google Classroom Untuk Meningkatkan Kemampuan Mahasiswa Dalam Membuat Perangkat Pembelajaran. Education and Human Development Journal, 5(1), 9-23.

Nurhayati, E. (2020). Meningkatkan keaktifan siswa dalam pembelajaran daring melalui media game edukasi quiziz Pada Masa Pencegahan Penyebaran Covid-19. Jurnal Paedagogy, 7(3), 145-150.

PP. (2013). Standar Nasional Pendidikan Patent No. Nomer 32.

Pratiwi, W. P. (2020). Penyelenggaraan Model Pembelajaran Daring MelaluiPemanfaatan Media Audio Visual Televisi Terhadap Motivasi Belajar Siswa Kelas VI SD Negeri Kendal (Doctoral dissertation, STKIP PGRI PACITAN).

Priyambodo, E., Wiyarsi, A., \& Permanasari, L. (2012). Pengaruh media pembelajaran interaktif berbasis web terhadap motivasi belajar mahasiswa. Jurnal Kependidikan: Penelitian InovasiPembelajaran, 42(2).

Riyana, C. (2019). Produksi Bahan Pembelajaran Berbasis Online. UniversitasTerbuka.

Sardiman, A. (2011). Interaksi dan Motivasi Belajar Mengajar. Jakarta: PTRajagrafindo.

Sugiyono. (2016). Metode Penelitian Kuantitatif. Bandung: Alfabeta.

Suhana, C. (2014). Konsep Strategi Pembelajaran. Bandung: PT Refika. Aditama. Suhery, S. P. (2020). Sosialisasi Penggunaan Aplikasi Zoom Meeting dan Google Classroom pada Guru di SDN 17 Mata Air Padang Selatan. Jurnal Inovasi Penelitian, 1(3), 129-132.

Sujarweni, Wiratna. 2014. Metodologi penelitian: Lengkap, praktis, dan mudahdipahami. Yogyakarta: PT Pustaka Baru.

Susanto, A. (2016). Teori Belajar dan Pembelajaran di Sekolah Dasar. Jakarta: Prenada Media Group.

Suyono, \& Hariyanto. (2015). Implementasi Belajar dan Pembelajaran. Bandung: PT.Remaja Rosdakarya.

Teni, N. (2018). Pengembangan Media Pembelajaran Untuk Meningkatkan. Jurnal Media Pembelajaran, 7-8.

Uno, H. B. (2011). Belajar dengan Pendekatan PAILKEM: Pembelajaran Aktif Inovatif Lingkungan Kreatif Menarik. Jakarta: Bumi Aksara.

Widiasih, R., Widodo, J., \& Kartini, T. (2018). Pengaruh Penggunaan Media Bervariasi dan Motivasi Belajar Terhadap Hail Belajar Mata Pelajaran Ekonomi Siswa Kelas XI IPS SMA Negeri 2 Jember Tahun Pelajaran 2016/2017. JURNAL PENDIDIKAN EKONOMI: Jurnal Ilmiah Ilmu Pendidikan, Ilmu Ekonomi dan Ilmu Sosia, 11(2), 103-107.

Wulandari, B. \&. (2013). Pengaruh problem-based learning terhadap hasil belajar ditinjau dari motivasi belajar PLC di SMK. Jurnal Pendidikan Vokasi, , 3(2). 